\title{
Agriculture as a factor of sustainable development in the Republic of South Ossetia
}

\author{
Lira Gurieva ${ }^{1 *}$, Nodar Kaberty ${ }^{1}$, and Irina Dzhioeva ${ }^{2}$ \\ ${ }^{1}$ North Ossetian State University, Vatutina Str., 44-46, 362000 Vladikavkaz, Russia \\ ${ }^{2}$ South Ossetian State University, Moskovskaya Str., 8, 500200 Tskhinval, Republic of South Ossetia
}

\begin{abstract}
In the recent history of the Republic of South Ossetia many projects aimed at providing the financial and economic basis for the country's sustainable development have been put forward. Some experts believed that the revenues from exporting mineral water alone are sufficient for the economic prosperity of South Ossetia; other experts suggested developing forestry in order to fill the state budget. Many hopes were also attached to the creation of modern production facilities based on nanotechnology and electronics. However, potential investors considered the initiated high-tech production to be high-risk, and the implemented projects in the light and construction industries did not bring expected benefits. Agriculture of South Ossetia has sharply declined after the wars in the course of formation of statehood 1991-1992 and 2008, but with an effective state policy for the integrated development of rural areas in the near future it can ensure the country's food security, create a basis for further competitive development of the economy, and facilitate the return of the country's residents who migrated as a result of two wars. Based on the international experience of state support, the article defines the factors of sustainable development of rural areas in the Republic of South Ossetia.
\end{abstract}

\section{Introduction}

By the time of its collapse in 1992 the Soviet Union included Georgia (the territory of 69.7 thousand sq km, population 5 million 494 thousand), which itself included Abkhazia (the area of 8.6 thousand sq km; population 533.8 thousand people), South Ossetia (the area of 3.9 thousand sq. km, population 100 thousand) and Adjara (the area of 3 thousand sq km; population 382 thousand) [1]. In the run-up to the collapse of the Soviet Union, an interethnic conflict broke out between Georgians and Pro-Russian Ossetians, who were persecuted and expelled from both Georgian territories and South Ossetia itself. This conflict soon turned into an inter-ethnic war that lasted until 1992, when the people of South Ossetia seceded from Georgia and declared their sovereignty. As a result of the inter-ethnic war, the economy of South Ossetia was severely destroyed, and more than 60 thousand Ossetians became refugees, settling mainly in the southern regions of the Russian Federation.

In August 2008, there was a repeated military invasion of South Ossetia by Georgian troops. The war lasted only five days, but it caused serious damage to the entire national

\footnotetext{
* Corresponding author: 443879@mail.ru
} 
economy and population of the country. According to international experts, as a result of military actions in the capital of South Ossetia, Tskhinvali, about $70 \%$ of buildings and structures were destroyed, $20 \%$ of medium and high-severity destruction, and $10 \%$ of the destruction could not be restored [2]. It is possible to assess the damage to state and municipal facilities - roads, gas and electricity - based on financial investments for their partial restoration, which cost only the Russian side 0.5 billion dollars. The damage to the private sector in South Ossetia is estimated at even greater amounts, and the damage to human capital caused by negative migration of the population cannot be estimated economically. Today, there are serious problems in the spatial development of the economy of the young state: against the background of general demographic problems of population aging and low birth rate, there is a dangerous depopulation of rural areas. This is because the level of poverty in rural areas of South Ossetia is significantly higher than in the city, there is a low level of access to social and engineering infrastructure, and in empty villages there is a process of reducing hospitals and schools. At the same time, the Republic has land, production and labor resources that can and should be involved in the development of agro-industrial production, including on an innovative basis. At the beginning of 2019, the Republic of South Ossetia had: agricultural land with a total area of 127677 hectares, livestock - 15120 heads, sheep 2940 heads, pigs -3434 heads, poultry -31655 heads. However, according to the official statistics of South Ossetia, out of 14481 hectares of sown area in 2018, only 2540.2 hectares of agricultural crops were cultivated and sown. [2]. With arable land, pastures and hayfields that are significant for achieving food security, South Ossetia provides itself with food only at the level of $37-38 \%$, the rest comes from food imported from neighboring countries [3].

The main reasons for the decline in agriculture in the Republic of South Ossetia are, according to generally accepted estimates, low productivity due to the use of outdated equipment and technologies, as well as the unattractiveness of the countryside as a place to live and work, especially for young people. At the same time, the involvement of at least part of the unused land resources in agricultural circulation will increase the level of food selfsufficiency of the population, create additional jobs, which will contribute to an increase in the living standard of the rural population. The need to identify the key factors for sustainable development of agriculture in the Republic of South Ossetia in order to increase the productivity of the agrarian economy predetermined the topic of this study.

\section{Materials and Methods}

Historically, agricultural development has focused on the exploitation of resource-intensive natural resources such as livestock, crop production and forestry. However, the global changes in the international division of labor that have taken place in the world, as well as the intensification of the processes of urbanization, migration and mobility of people, have changed the nature of rural areas development in almost all regions of the Earth. The rich and varied experience accumulated in different countries shows that the further growth of agriculture in the 21 st century requires not only new technologies of agricultural production, but also new methods of designing sustainable development of rural areas, strengthening state regulation based on a program-targeted approach, which in principle is still absent in the understanding of the political and administrative elite of the Republic of South Ossetia (RSO). The modern development of agriculture in RSO is built on a directive basis with a high role of state regulation of investment and production activities: The Ministry of Agriculture of South Ossetia annually allocates commodity loans to farmers; helps them with seeds of winter crops; the state pays for the $50 \%$ of the mechanized work, which is carried out by the state enterprise «IrAgroPromService». The state also laid the foundation for the «Gardens of Iriston» with an area of 52 hectares, etc. However, such a policy plays the role of support, not development of agriculture. The problem of finding new mechanisms of state 
regulation of the agrarian economy based on the best foreign practices of sustainable development of rural areas is obvious. However, the world experience in regulating the agrarian economy within the framework of the sustainable development paradigm is very diverse, has regional specifics and cannot be blindly borrowed, which makes the problems of generalization and selection for effective adaptation in agriculture of the RSO actual.

The subject of this research is organizational, managerial, financial and economic methods of state regulation of agriculture and the agricultural economy in a number of countries in Europe, the United States and China.

The aim of the work is to study the successful international experience of systemic approaches of state support for the development of the agrarian economy and its adaptation to the agricultural conditions of the Republic of South Ossetia.

In the course of the research, the methods of institutional, evolutionary and comparative analysis of the types, directions and volumes of state support for agriculture in the USA, EU countries and China were used.

\section{Results and Discussion}

In order to use foreign experience of state support of the agricultural sector, despite the incomparability of the size and power of the RSO economy with developed countries, the experience of China, the USA and the EU countries is of considerable interest, since the republic is comparable with some regions of these countries in terms of natural resource conditions and potential structure of agrarian economy. According to the ranking of the largest exporters of agricultural products in the world AGRONEWS 2015, the total income of China from agriculture was $\$ 1.088$ trillion. In 1990-2015, China was the leader in cereal production, occupying one of the leading places in the variety of crops grown. The country has about $40 \%$ of the total pig population in the world, about $10 \%$ of all sheep and goats, as well as 5\% of cattle. Exports of agricultural products in China in 2017 amounted to $\$ 2.157$ trillion. [4]. Today, this country - undoubtedly the largest exporter of agricultural products in the world - is very close to producing as much agricultural products as the rest of the top 10 countries with the most developed agriculture combined. The total income of the United States from agriculture in 2015 amounted to $\$ 290$ billion. In the 2015 ranking of AGRONEWS Top-10, the United States ranks first in the production of corn and soybeans, and the third in the collection of sugar beets. $16 \%$ of the total world grain harvest is grown here. In the United States, more than 2.5 million private farms are supported in one form or another, employing more than 20 million people. Natural factors, the use of the achievements of scientific and technological progress, as well as significant investment from the state are factors that contribute to the steady development of agricultural production in the United States. Exports of US agricultural products in 2017 amounted to $\$ 1.576$ trillion. [4]. France and Germany are the largest food producers in the EU. The volume of exports of agricultural products in Germany in 2017 amounted to $\$ 1.401$ trillion. It should be noted that most of the agricultural producers are small enterprises. France ranks first in the EU for the production of grain, milk, sugar beet, and second for the production of meat, potatoes and grapes. In terms of foreign trade turnover ( $\$ 58 \mathrm{bn}$.), France ranked 4 th in the world in the AGRONEWS Top 10 ranking in 2015 [5]. Exports of agricultural products in France in 2017 amounted to $\$ 551.8$ billion [4].

It should be noted that in these states significant budgetary allocations are made to support agriculture, and the volume of state support for agriculture has been steadily growing over the past decades. China became the world leader in terms of overall government support in 2018 , with funding of over $\$ 342$ billion. The level of aggregate support to the agricultural sector in the United States is $\$ 139.6$ billion and the European Union states is $\$ 57.9$ billion 
(Table 1). In terms of its share in gross domestic product, the USA is the leader, where state financing of agriculture in GDP is $6.8 \%$, in China $-3.6 \%$, in the EU $-3.4 \%$. (Table 2).

Table 1. Dynamics of budget allocations for the development of agriculture in the USA, China and the EU in 1990-2018, billion US dollars [6, 7, 8]

\begin{tabular}{|c|c|c|c|c|c|c|c|c|c|}
\hline & $\mathbf{1 9 9 0}$ & $\mathbf{2 0 0 0}$ & $\mathbf{2 0 1 0}$ & $\mathbf{2 0 1 3}$ & $\mathbf{2 0 1 5}$ & $\mathbf{2 0 1 6}$ & $\mathbf{2 0 1 7}$ & $\mathbf{2 0 1 8}$ & $\begin{array}{c}\mathbf{2 0 1 8} \text { to 1990, } \\
\text { times }\end{array}$ \\
\hline USA & 45.9 & 75.1 & 135.8 & 155.9 & 139.1 & 138.1 & 138.9 & 139.6 & 3,04 \\
\hline China & 20.0 & 25.0 & 150.0 & 250.0 & 325.0 & 358.7 & 349.2 & 342.8 & 17,14 \\
\hline EU & 24.9 & 37.7 & 71.8 & 72.4 & 79.8 & 62.8 & 54.4 & 57.9 & 2,33 \\
\hline
\end{tabular}

Table 1 shows that the budgetary expenditures for supporting agriculture in the period 1990-2018. in China they grew more than 17 times, in the USA - 3,04 times, in the EU - 2,33 times.

Table 2. Total government support for agriculture in the US, China and the EU in 2018 [9]

\begin{tabular}{|c|c|c|c|}
\hline & $\begin{array}{c}\text { Budgetary allocations for } \\
\text { agricultural development, USD } \\
\text { billion }\end{array}$ & $\begin{array}{c}\text { GDP (USD } \\
\text { trillion) }\end{array}$ & Share in GDP, \% \\
\hline USA & 139,6 & 20,237 & 6,8 \\
\hline China & 342,8 & 13,040 & 2,6 \\
\hline EU & 57,9 & 15,800 & 3,6 \\
\hline
\end{tabular}

In the study of foreign experience of state support for the agricultural sector, the experience of China, which joined the WTO in 2001, is of particular interest. As time has shown, it was precisely the implementation of targeted protectionist state policy and successive agrarian reforms that allowed the country to significantly increase the volume of agricultural production and become the largest producer in the world food market. The modern mechanism of state support for agriculture in China makes extensive use of administrative and economic methods of state regulation. At the same time, the country has no obligations to reduce aggregate support measures, since during the negotiations on China's accession to the WTO, individual commitments of the country were agreed for the long term [10].

The European Union has the most effective system of state support for the agricultural sector. Since 1962, support for agricultural producers in European countries has been carried out within the framework of the regularly updated Common Agricultural Policy (CAP). Implementation of the current CAP 2014-2020 aims to achieve sustainable agriculture and balanced territorial development in Europe, ensuring a sustainable supply of safe, high quality products for 500 million EU citizens at affordable prices, and ensuring a reasonable income level for 11 million EU farmers [11]. The program plays a critical role in terms of social, environmental and economic development in European rural areas, it operates in three main areas: allocation of subsidies to producers (Producer Support Estimate - PSE), budgetary financing of general services (General Services Support Estimate - GSSE) and transfers consumers and their ratio.

To implement these areas, the EU government uses almost all measures of state regulation of agriculture developed in the WTO: import duties, quotas for import supplies, price support through government interventions, production quotas and taxes for land non-use.

However, it is important to note that institutional regulation in agriculture of the EU countries is carried out with a bias in support of capital-intensive organizations. To do this, government agencies use tools that contribute to the accelerated development of highly profitable farms and agricultural holdings. At the same time, small-scale farms do not have sustainable growth prospects, since their resource potential does not allow farmers with low incomes to compete in the domestic and foreign markets. Due to the low income of a certain 
group of agricultural producers, the number of individual and family farms in the EU countries for the period from 2014 to 2018 decreased from 28.5 to 19.1 million farms, while the number of agricultural holdings belonging to the category of large agricultural organizations, on the contrary, increased from 9.6 to 9.9 million units [12]. This is due to the active use of institutional rules that stimulate the process of allocating financial capital in favor of highly profitable economic structures. In accordance with the current regulations in the EU countries, subjects of various forms of ownership can receive state financial support on preferential terms, which should be distributed among all farms, but in fact, the budgetary resources of Western European states accelerate the development of highly profitable farms and agricultural holdings, infringing on the competitive opportunities of small farmers. In 2018, European farmers with the volume of products sold up to 200 thousand euro received $36 \%$ of government subsidies, the rest went to support large agricultural holdings [13].

In the United States, the state policy of supporting agriculture in 2014-2018 was also clearly focused on maintaining the competitiveness of export-oriented large farms. According to official statistical reports, direct government payments to farmers in 2014-2018 increased 2.1 times, although the increase in their income was only $14.3 \%$. Over a 5 -year period, owners of large farms received $62.4 \%$ of these payments, or $54.8 \%$ more than the amount of subsidies received for the use of small-scale farms [14].

In September 2015, world leaders adopted the UN Agenda «Transforming Our World: The 2030 Agenda for Sustainable Development». It sets out 8 Millennium Development Goals aimed at eradicating poverty and hunger, protecting the planet, protecting human rights and ensuring prosperity for all. The adoption of this Agenda marks a historic shift towards a new paradigm through a universal and comprehensive solution to economic, social and environmental inequalities.

Within the framework of the Agenda 2030, the key policy areas of transformational change towards sustainable development were identified: transition to a low-carbon, closed and resource-efficient economy; socially inclusive society and economy - decent work and human rights; sustainable production and consumption of food; trade for global sustainable development. And the preconditions for such transitions already exist in the world. Thus, based on large-scale studies of the development of the OECD countries 'economies, Ward N. and Brown D. noted that the replacement factor for the development of even economically efficient rural areas in the 21st century is not agriculture, but various types of tourism and recreation, niche industries [15]. However, as Van Assche Kristof \&Hornidge AnnaKatharina rightly points out, unlike urban areas, which have much in common, modern rural areas are very different from each other. For this reason, a wide variety of approaches to rural development are used around the world. At the same time, rural governance and development are inextricably linked in all successful countries, and «the rural community is much better at strategizing when it understands the links of sustainable development» [16]. Thus, modern rural development is an all-encompassing term. It mainly focuses on development activities outside the main urban economic system.

Note that as different approaches to the development of rural areas, so different are the problems associated with this development. First of all, we are talking about overcoming the technological trend of reducing the population of rural areas. «The world should think about what new type of rural development we need, because rural modernization leads to urbanization, and the rural environment disappears», - concludes the head of the Department of the European economic and social Committee, Staffan Nilssonin his report «Towards a more balanced territorial development». These conclusions are confirmed by the Nilsson report, which states that «in the Eastern and southern EU countries, there is an alarming trend of a growing flow of young people leaving their hometowns in search of work in remote cities, but the constantly growing global demand for food in the near future will undoubtedly require the cultivation of all agricultural land» [17]. Staffan Nilsson stressed that leaving 
large production areas for foreign corporate investors is a luxury that the EU cannot afford. It is one thing to temporarily postpone a field, but letting the surrounding infrastructure (often built over decades) be destroyed that makes sustainable and profitable agriculture possible is another.

It should be added to Nilsson's conclusions that the concentration of economic activity in urban areas is not sustainable in the long term. It invariably creates a significant load on natural resources (air, water, soil), and thus creates high risks of a significant deterioration in the quality of life of urban residents in the future $[18,19]$.

Project of new CAP for 2021-2027 proceeds from the premise that having good employment opportunities is a necessary but not sufficient condition for securing young workers in their rural areas or returning them if they have already left rural areas. Education and health services, ICT connections, even cultural events must reach a minimum level that makes life in these places not only acceptable but also truly attractive. Since CAP 2021-2027 is based on a cross-cutting integrated approach and affects almost any EU policies, it is assumed that a balanced territorial dimension will be taken into account as a criterion for sustainability in any European development program.

\section{Conclusions}

As a result of research authors got significant conclusions that are recommended to be taken into account when developing a state policy to support the development of agriculture in the Republic of South Ossetia:

1. The creation of competitive agriculture in the modern world is impossible without strengthening the role of the state and supporting this sector of the economy. In particular, there are three main priority areas in the composition of state support: Producer Support Estimate (PSE), General Services Support Estimate (GSSE) and transfers to consumers and their ratio.

2. The instruments of state support currently used, with their general similarity in different countries, have a certain specificity: each country develops its own approaches to agricultural policy, has a certain system of state support, taking into account the characteristics of the country, territories, economic and social conditions, norms of public life and mentality.

3. All major agrarian powers have seen a decline in small-scale farming. Despite the urgent need to stimulate the family farming, the institutions of the United States and the European Union countries are focusing efforts on increasing the competitiveness of exportoriented farms, which leads to serious problems of rural migration to cities and the rapid destruction of the historically established rural structure. In turn, this reduces the sustainability of the development of the agricultural economy.

4. The Government of the Republic of South Ossetia should apply a systematic approach to agricultural development from a broader perspective of rural development: it is necessary to expand the goals from primarily creating incentives for agricultural or resource enterprises to a wide range of goals for sustainable development of rural areas.

\section{Acknowledgements}

The reported study was funded by the Russian Foundation for Basic Research (RFBR), according to the research project No 20-510-07003 MON RYUO_a «Development of the agricultural sector as a factor in improving the standard of living and the migration attractiveness of the Republic of South Ossetia». 


\section{References}

1. D. Rayfield, Edge of Empires:A History of Georgia (2012)

2. E.Y. Kharebov, I.K. Totrova, T.A. Kazakhova, Economics and Entrepreneurship, 8, 1139 (2019)

3. E.Y. Kharebov, I.K. Totrova, T.A. Kazakhova, Economics and Entrepreneurship, 8, 1180 (2019)

4. The world factbook CIA (2017), https://www.cia.gov/

5. D. Zanko, TOP-10 of the largest agricultural countries in the world (2017), https://agronews.com/

6. Government finance statistics - Summary tables (2019), https://ec.europa.eu/

7. Budget of the U.S. Government. FiscalYear (2018), https://www.govinfo.gov/

8. National Bureau of Statistics of China (2019), http://www.stats.gov.cn/

9. Overall Assessment of Agricultural Support 2018. OECD Economic Research Service, https://stats.oecd.org/

10. S.M. Gorlov, G.I. Panaedova, A.I. Borodin, Bulletin of the North Caucasus Federal University, 6 (2019)

11. Overview of CAP Reform 2014-2020. Agricultural Briefon CAP, 5 (2013)

12. FAO Production Yearbook 2018, 235 (2019)

13. Statistical Abstract of the United States 2018 (2019)

14. Agricultutal, forestry and fisheries. Eurostat yearbook (2018)

15. N. Ward, D.L. Brown, Regional Studies, 43 (2009)

16. V. Assche, Kr. Hornidge, Rural development. Knowledge \& expertise in governance, (2015)

17. St. Nilsson, Towards a more balanced territorial development, (2014)

18. A. Kurbanov, L.K. Gurieva, S.N. Novoselov, O.A.Gorkusha, N.N. Novoselova, and A.A. Kovalenko, International Review of Management and Marketing, 6 (1) (2016)

19. I.L. Litvinenko, L.K. Gurieva, O.N. Baburina, M.A. Ugryumova, and V.I. Kataeva, International Business Management, 10(22) (2016) 